“A TEMPORARY SYMBOL OF A CANADIAN DREAM IN THE MAKING": RESOURCE EXTRACTION AND GENDER-BASED VIOLENCE AGAINST INDIGENOUS WOMEN

by

\author{
Vanita Clare \\ Honors Bachelor of Arts \\ in the programs of Political Science and Criminology and Socio-Legal Studies \\ University of Toronto, 2018
}

\author{
A Major Research Paper \\ presented to Ryerson University \\ in partial fulfillment of the \\ requirements for the degree of \\ Master of Arts \\ in the program of \\ Public Policy and Administration
}

Toronto, Ontario, Canada, 2019

(C) Vanita Clare, 2019 


\section{Author's Declaration}

I hereby declare that I am the sole author of this MRP. This is a true copy of the MRP, including any required final revisions.

I authorize Ryerson University to lend this MRP to other institutions or individuals for the purpose of scholarly research.

I further authorize Ryerson University to reproduce this MRP by photocopying or by other means, in total or in part, at the request of other institutions or individuals for the purpose of scholarly research.

I understand that my MRP may be made electronically available to the public. 


\title{
"A Temporary Symbol of a Canadian Dream in the Making": Resource Extraction and Gender-Based Violence Against Indigenous Women
}

\author{
Vanita Clare, Master of Arts
}

Public Policy and Administration, Ryerson University, 2019

\begin{abstract}
The purpose of this paper is to analyze the gendered implications of Canada's resource extraction industry. To further explore this dynamic, this paper will look at how Indigenous women and girls are impacted by primarily three labour practices adopted by the resource sector: establishing "man camps", creating demanding work environments, and providing excess levels of income. These labour conditions imposed by resource companies have created a culture within the sector known as "rigger culture" that is marked by sexist, aggressive rhetoric and a partying attitude that encourages the consumption of drugs and alcohol. This rigger culture has successfully reinforced historical patterns of colonial relations, and disproportionately exposes Indigenous women to various forms of gender-based violence. Men within the resource sector are engaging in harmful behaviour that exacerbates existing political, social, and economic disadvantages. The paper then concludes with policy recommendations aimed at addressing the root cause of violence against women in the industry and neighbouring resource regions.
\end{abstract}




\section{Table of Contents}

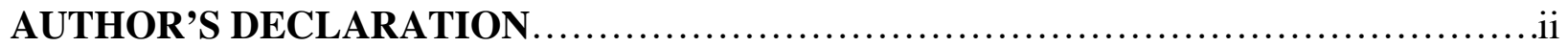

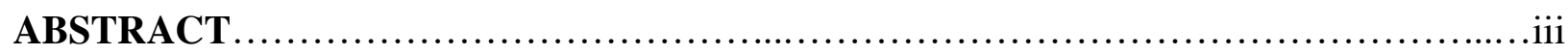

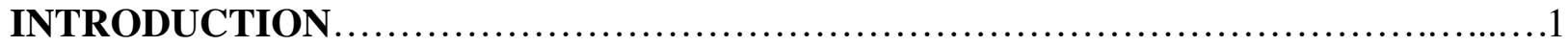

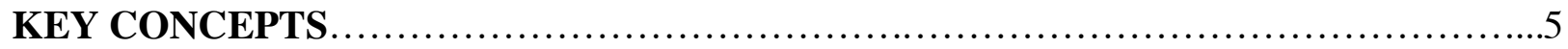

LITERATURE REVIEW ........................................................

CANADA'S HISTORY AS A COLONIAL STATE................................ 12

MISSING AND MURDERED INDIGENOUS WOMEN AND GIRLS ............................16

LABOUR PRACTICES OF THE EXTRACTIVE INDUSTRY ...................... 18

Canada's Resource Industry at a Glance ...........................................18

The Capitalist System .....................................................20

Establishing Man Camps.................................................. 22

Creating Demanding Working Conditions ......................................24

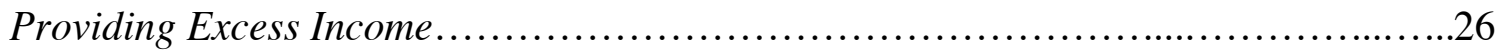

RIGGER CULTURE AS GENDER-BASED VIOLENCE...........................29

POLICY RECOMMENDATIONS ............................................. 34

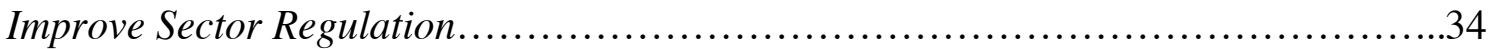

Increase Supports and Services........................................... 37

Ensure Free, Prior, and Informed Consent .................................... 39

CONCLUSION ............................................................. 42

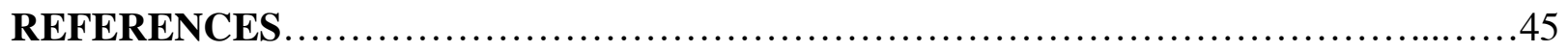




\section{Introduction}

The Nak'azdli Whut'en First Nation reside in North-Central British Columbia, on the banks of Stuart Lake with approximately 1,972 members living on and off reserves. Located in a resource region, this community has long struggled with the implications of resource development on their lands. As it currently stands, there are three proposed projects within the area: The Coastal GasLink pipeline, the North Montney Mainline pipeline, and the Prince Rupert Gas Transmission pipeline. It is estimated that within the next decade, as many as 6,000 industry workers could move into the region. ${ }^{1}$ This influx of workers would more than double the population in Fort St. James, which includes many rural and First Nation communities. There is an unspoken reality that comes with this kind of rapid development of Canada's resource economy, which has led the Nak'azdli Health Centre to assemble rape kits to gather physical evidence as a way to protect women in response to these proposed projects. ${ }^{2}$

This type of preparation reflects one of the consequences of resource development and extraction. The highly controversial nature of extractive projects is due in part to environmental concerns, but less noted by the media are the social implications. The extractive industry depends upon a transient workforce to maintain levels of productivity and development. Projects draw workers from across Canada to fill mobile housing units - or the aptly named "man camps" - in the region of development. To men who are travelling across the country for resource work, these housing units that disproportionately house male workers are a "temporary symbol of a Canadian dream in the making." ${ }^{3}$ They fuel the local and broader economy and are seen as a necessary part

\footnotetext{
${ }^{1}$ Morin, Brandi. "Pipeline 'man camps' loom over B.C.'s Highways of Tears." Canada's National Observer. September 21, 2017. https://www.nationalobserver.com/2017/09/21/news/pipeline-man-camps-loom-over-bcshighway-tears

${ }^{2}$ Ibid.

${ }^{3}$ Kyle Edwards, "How we treat women," Macleans, May 13, 2019, https://www.macleans.ca/how-we-treatwomen/.
} 
of resource extraction. But they are also a part of the larger culture of energy development, and provide the necessary labour for industries to profit from exploiting the earth's riches. All too often this profit maximization is done at the expense of the environment and local communities. Compounded by harmful social conditions, the communities located in these resource regions are inherently at risk of gender-based violence with the mass influx of men into local work camps. But the end goal for local and provincial governments is a growing economy, jobs, and energy development. So, who would argue with that?

There is a dominant narrative that frames resource extraction as an activity that contributes to economic prosperity, resource development, and Canada's image as a resource rich country. But the rapid development of Canada's resource economy has long lasting, and often fatal, social implications. These are implications that have impacted resource regions and nearby communities for years, in particular impacting vulnerable segments of Canada's population in neighbouring municipalities and communities. Canada is steeped in a colonial history of cultural erasure that stems from the exploitation of land and dispossession of Indigenous peoples. The history of clearing the land of Indigenous communities to gain access to natural resources is based on the idea that these communities are disposable. It is necessary to understand the way in which colonialism has gendered implications that sustain current levels of structural inequality.

The exploitation of land and resources for economic gain is rooted in a capitalist system that creates and maintains unequal power relations. Those that control the means of production, and generate profit, often hold the power. Once money stops circulating within a capitalist state, the entire system is in crisis. However, when that money begins to circulate, the "exploitation of the earth and its people intensifies, straining both and creating new conditions for instability and 
unrest." ${ }^{4}$ Establishing a nation on resource exploitation and the circulation of capital creates dependencies that are difficult to break. Finding themselves at the centre of this relationship are Indigenous peoples. Resource development, oil extraction, mining, and pipelines are made possible by "the outright dismissal of Indigenous treaty rights, self-determination and sovereignty." As a result, the active denial of Indigenous rights is a necessary component for the state to maintain constant levels of resource extraction and economic growth.

Private corporations building pipelines, fracking, mining, and engaging in numerous other forms of resource development have adopted policies and practices to ensure profitability. Part of maintaining this profit is employing labour practices that support that goal. These labour practices become the way in which extractive industries impact First Nation, Métis, and Inuit communities. The central argument put forth in this paper is that there are negative gendered implications that arise from the extractive industry's adoption of harmful labour practices. The resource industry is marked by a dangerous "rigger culture" that is a byproduct of primarily three labour strategies: the creation of man camps for transient workers; highly demanding work conditions; and disposable amounts of income. This rigger culture facilitates both direct, and indirect conditions in which Indigenous women face various forms of violence.

More specifically, this paper will look at how the resource extraction industry disproportionately exposes Indigenous women in Canada to forms of gender-based violence. By looking examples in British Columbia and the Bakken oil fields in North Dakota, I will demonstrate how resource extraction and its impacts go beyond environmental degradation and produce violent gendered implications on nearby communities. Resource extraction creates a

\footnotetext{
${ }^{4}$ Brett Story, Prison Land: Mapping Carceral Power across Neoliberal America. (Minneapolis: University of Minnesota Press, 2019), 17.

${ }^{5}$ Jen Preston, "Neoliberal Settler Colonialism, Canada and the Tar Sands," Race \& Class, 55, no. 2 (2013): 47.
} 
culture and conditions in which Indigenous women experience heightened levels of violence. This rigger culture is characterized by increased levels of drugs and alcohol consumption, crime, purchasing sex, and a hyper-masculine environment that exacerbates existing political, social, and economic marginalization that First Nation, Métis, and Inuit women face.

This paper will first aim to define key concepts and terms in an effort to build a base understanding of this topic. Then I will pull together the existing literature to highlight research that has been conducted within this area, and the dominant themes that have emerged as a result. Next, this paper will describe in detail Canada's history as a colonial state and the ways in which it has impacted existing realities for Indigenous peoples till this day, including providing insight into the crisis of Missing and Murdered Indigenous Women and Girls. The following section will analyze the extractive industry, the adoption of capitalism, the dominant labour practices that are employed, and the impact it has on local communities. Finally, the last section will serve to bridge the gap between harmful labour practices of the extractive industry, and gender-based violence against Indigenous women and girls. The paper will then conclude with policy recommendations to address the deep-rooted issues within the sector, and ways to protect Indigenous women and girls in Canada. As a whole, this paper will look to explore the phenomenon of resource extraction, man camps, and rigger culture with a labour lens in order to understand how themes of capitalism, labour, and profit shape gendered experiences. 


\section{Key Concepts}

To understand the intersection of resource extraction, gender-based violence, man camps, and rigger culture, it is important to begin with a base understanding of these terms. Particularly because concepts such as rigger culture and man camps are not used in everyday speech, yet they hold power within resource communities who see the ramifications of resource extraction on a daily basis. To guide the discussion of gender-based violence in the context of resource extraction, it is essential that these concepts are defined in accessible ways.

The first term that requires defining as context for this paper is resource extraction. Resource extraction is the act of withdrawing materials, specifically primary resources, from the natural environment. ${ }^{6}$ Whether it is oil, minerals, gas, logging, or soil and nutrient removal, the extraction of these resources can be challenging and devastating for the environment and social fabric of surrounding communities. For example, mining involves creating open pits to withdraw the materials, logging requires clearing the land, and oil extraction extensively disrupts the surface of the earth. ${ }^{7}$ Removing natural resources from its existing place has become a cornerstone of Canada's economy. As this paper will explore, the extractive industry plays a vital role in Canada and has a multitude of harmful implications.

Another concept that is essential to define is gender-based violence. Plan International is an international development and humanitarian organization that works to advance children's rights and gender equality across 71 countries around the world. According to Plan International, gender-based violence is a structural problem that is embedded within unequal power relations between women and men, and this relationship has led to a negative disproportionate effect on

\footnotetext{
${ }^{6}$ Encyclopedia. "Resource Extraction." (2016). Retrieved from https://www.encyclopedia.com/environment/energy-government-and-defense-magazines/resource-extraction.

${ }^{7}$ Ibid.
} 
women. ${ }^{8}$ It is a form of discrimination that represses the extent that women and girls can exercise their inherent rights and freedoms. ${ }^{9}$ There are four reasons that help to explain how gender-based violence is facilitated. First, unequal power relations fuel the belief that sex or gender entitles certain abusive behaviour to harm or control someone ${ }^{10}$ Second, the value of women and girls are of low social status and this impacts the way in which society interacts with and treats them. ${ }^{11}$ The third reason is due to prevalent gender stereotypes and norms that justify violence when individuals do not meet those stereotype ${ }^{12}$; for example, when people do not conform to the gender binary, it is seen as deviating from gendered norms, which society seeks to punish. Finally, the most important factor behind gender-based violence is that it is often "condoned or perpetrated by governments as normal" and sanctioned through laws, policies, and state actions. ${ }^{13}$ There are many types of violence that affect women throughout their lives, and these can include physical violence, sexual violence, emotional or psychological violence, and economic violence. Collectively, these forms of violence are rooted in gender inequality and the idea that women and girls are "lesser than." This is a systemic issue that upholds and maintains power relations that seek to disadvantage women in the interest of men. Therefore, this violence is based upon sexist premises and notions of how gender should be defined and constructed by society.

Central to this paper is an analysis of the phenomenon of man camps or industrial camps that are a by-product of the expanding resource industry. Man camps are lands or living accommodations in "connection with a logging, sawmill, mining, oil or gas operation, a railway

\footnotetext{
${ }^{8}$ Plan International. "Gender-Based Violence”. (2019). Retrieved from https://plancanada.ca/gender-basedviolence.

${ }^{9}$ Ibid.

${ }^{10}$ Ibid .

${ }^{11}$ Ibid.

${ }^{12}$ Ibid.

${ }^{13}$ Ibid .
} 
construction project, [or] a cannery." ${ }^{14}$ Employers are responsible for establishing, owning, operating or maintaining, either permanent or temporary living quarters for their employees. ${ }^{15}$ These are forms of housing that are similar to refugee camps, labour camps, and disaster camps that arise for short-term employment to accommodate a surge in resource development in a given area ${ }^{16}$ For the transient workers that the extractive industry predominantly relies on, man camps are a way to provide shelter for them while being employed. It is a practice adopted within resource development that allows workers to live within the area to achieve maximum productivity and generate profit. As will be explored through this paper in more depth, these camps are a controversial symbol of the meaning of resource development. The implications of these camps, and the associated rigger culture, have detrimental impacts on resource-rich communities particularly on the women and girls within the area. As a result, these temporary living arrangements have become a symbol of violence in the extractive industry.

The theoretical concept of what is known as rigger culture is premised on the extractive industry and man camps or industrial camps. Many scholars and studies, such as The Peace Project, found that man camps are home to a distinct culture that characterizes the environment in which workers live. This culture is hyper-masculine, sexist, apathetic, and reinforces a party atmosphere filled with alcohol, drugs, and partying though the night. ${ }^{17}$ This thriving environment has become an identity of the workers within man camps which they are expected to exhibit. Rigger culture "creates complex sexual dynamics with women in nearby communities" 18 as the culture of hyper-

\footnotetext{
${ }^{14}$ Gibson et al., "Indigenous Communities and Industrial Camps: Promoting healthy communities in settings of industrial change." Firelight Group, (2017): 8.

${ }^{15}$ Ibid.

${ }^{16}$ William R. Caraher et al., "The North Dakota Man Camp Project: The Archaeology of Home in the Bakken Oil Fields." Historical Archaeology 50, no. 2 (2017): 268.

${ }^{17}$ Eckford, Clarice and Wagg. "The Peace Project: Gender Based Analysis of Violence against Women and Girls in Fort St. John.” (2015): 24.

${ }^{18}$ Eckford, Clarice and Wagg (2015): 20.
} 
masculinity, alcohol, drugs, and sexual violence creates dangerous conditions. Restrictive work environments of resource extraction lead to workers "blowing off steam" and engaging in reckless behaviour that creates situations where Indigenous women experience heightened levels of vulnerability. The identity that is tied to rigger culture and the extractive industry justifies the behaviour and treatment of women in the area. There is a dark reality that comes with resource extraction produced by this dangerous culture that normalizes violent behaviour against women and the excessive use of drugs and alcohol. 


\section{Literature Review}

The existing literature on resource development and man camps has largely examined the social implications of resource development on local regions. Scholars have asked fundamental questions about whether or not resource extraction leads to an increase in certain social behaviours. One dominant theme that is apparent within the scholarship is that an increase in a transient resource-based workforce brings crime into the region. A study by Komarek conducted in the U.S. found that counties with a natural gas boom - measured by 75 or more unconventional wells drilled in a year - see an approximate 30 percent increase in violent crimes. ${ }^{19}$ Komarek argues that this increase is due to the mostly young, male workers flocking to the region for work as they have been found to disproportionately participate in both violent crimes and property crimes. ${ }^{20}$ This finding is echoed by Dellar and Dellar who observed that the arrival of workers into a region causes social capital to deteriorate and crime to increase. ${ }^{21}$ A similar study conducted in Australia by Carrington, Hogg and McIntosh identified similar results based on reports that one Western Australian mining community saw the rate of violence increase to 2.3 times higher than the state average..$^{22}$

Scholars within the field have also put forth various reasons as to why resource regions bring an increase in crime and violence. For example, Komarek posited that a rapid change in demographics creates an imbalance in the sex ratio, and this encourages specific types of crime potentially crimes against women. ${ }^{23}$ Yet another resource-rich area, in North Dakota at the

\footnotetext{
${ }^{19}$ Komarek, T.M. "Crime and natural resource booms: evidence from unconventional natural gas production." (2018): 116.

${ }^{20}$ Komarek, T.M (2018): 119.

${ }^{21}$ Deller SC, Deller MA. "Rural crime and social capital." Growth Change, 41, no. 2 (2010): 221-275.

${ }^{22}$ Carrington, Hogg and McIntosh. “The Resource Boom's Underbelly: Criminological Impacts of Mining Development." (2011): 342.

${ }^{23}$ Supra note $18,119$.
} 
Williston Basin Region, also saw violent crime increase by 121 percent from 2005 to 2011 as oil began to boom. ${ }^{24}$ In an interview conducted by Horowitz, Timothy Q. Purdon, the U.S. Attorney for North Dakota stated that "more money and more people equals more crime." ${ }^{25}$ Furthermore, the idea of transient workers increasing crime within resource regions has been echoed by Amnesty International in their leading report titled "Out of Sight, Out of Mind." This international humanitarian organization found that the mostly-male workforce in the resource sector creates a risk for local communities as young men are statistically more likely to commit violent crimes. ${ }^{26}$ Amnesty International noted that during a period of layoffs or the annual "spring break-up" when job sites are closed while the ground thaws, violence against women increases notably. ${ }^{27}$ The high use of services and resources such as women's shelters and health centres in the region paint a picture of increasing violence and crime. Thus, the existing literature has positioned man camps and the effects of resource extraction as having a criminological impact on the region.

The second theme that is presented in the literature is how man camps are part of a historical relationship of violence and colonialism. According to a report by Downtown Eastside Women's Centre titled Red Women Rising, “extractive violence on Indigenous lands is connected to violence against Indigenous women." ${ }^{28}$ Similar findings were found by The Firelight Group report written with Lake Babine Nation and Nak'azdli Whut'en First Nation that serves to spotlight the historical relationship between colonization and gender-based violence. The report found that the mobile nature of an industrial workforce "reinforces and recreates historical patterns of

\footnotetext{
${ }^{24}$ Sari Horowitz, "Dark Side of the Boom," The Washington Post, 28 September 2014.

${ }^{25}$ Ibid.

${ }^{26}$ Amnesty International. "Out of Sight, Out of Mind: Gender, Indigenous Rights, And Energy Development in Northeast British Columbia, Canada," (2016): 4.

${ }^{27}$ Supra note 25, 44.

${ }^{28}$ Martin, Carol Muree, Walia, Harsha. "Red Women Rising.” Downtown Eastside Women's Centre, (2019): 61.
} 
violence against Indigenous women." ${ }^{29}$ Therefore, there is an understanding that an influx of men into a region increases the chances of violence against Indigenous women as they already face historical forms of political, social and economic marginalization. A fundamental idea in the literature that will be explored in this paper: violence and crime exist along gendered lines. However, as this paper will suggest, there is a gap in the literature that addresses resource extraction's gendered impact from a labour perspective. This means exploring what labour practices looks like within the resource industry in Canada, including how conditions within man camps are a byproduct of a larger labour system. What does not exist within academic writing is an analysis of how a combination of specific, yet independently inconsequential, labour practices contribute to the gendered violence and crime in resource regions. Therefore, this paper will analyze themes of capitalism, labour, and gendered experiences to understand how resource extraction negatively impacts women and girls.

${ }^{29}$ Gibson, G., K. Yung, L. Chisholm, and H. Quinn with Lake Babine Nation and Nak'azdli Whut'en. "Indigenous Communities and Industrial Camps: Promoting healthy communities in settings of industrial change." (2017): 6. 


\section{Canada's History as a Colonial State}

European settlers exerting power and control over Indigenous peoples is central to understanding contemporary race relations, gender-based violence, man camps, and rigger culture. The colonization of Canada has created systems of power that characterizes the current relationship between Indigenous peoples and the state. The introduction of western governance systems and the establishment of the Canadian state at the expense of Indigenous communities has allowed for new forms of systemic race and gender-based discrimination to arise. The way in which various institutions of the state were established on the basic premise of colonialism and exploitation helps in understanding modern forms of violence against First Nation, Métis, and Inuit women. The entanglement of race and power has established a system where Indigenous women are disproportionately exposed to the harmful racialized dynamics of Crown-Indigenous relations. As racial hierarchies were established within the Canadian landscape, it began relegating Indigenous peoples to the peripheries of society, leaving power in the hands of European settlers. This transfer of power was legitimized with the introduction of the Indian Act, 1876. This controversial act has resulted in of conditions of economic, political, and social inequality for Indigenous communities who are rendered without "legitimate" power.

Loss of power of Indigenous groups and women, has led to the denial of rights, land, social, political, and economic freedom. A main source of legislation that has historically disempowered Indigenous women is the Indian Act, 1876. This Act is rooted in paternalistic beliefs, control, and segregation of Indigenous peoples on reserve lands. ${ }^{30}$ The introduction of the patriarchy was enacted through initial contact, and imposed upon the matriarchal cultures of Indigenous peoples

\footnotetext{
${ }^{30}$ Inter-American Commission on Human Rights. "Missing and Murdered Indigenous Women in British Columbia, Canada." (2014): 23.
} 
where Indigenous women were the givers of life, keepers of tradition, and equal members with respect and authority. ${ }^{31}$ Imposing European forms of patriarchy was a way to target the "power of Indigenous women as decision makers, leaders and equal members of their community." ${ }^{32}$ Legalizing such social systems was done through the Indian Act, effectively erasing the power and role that women played within various nations and replacing it with male dominated systems. For example, the legal status of "Indian" was defined within the Indian Act, and outlines standards in order to be registered as one..$^{33}$ It has been noted that historically, Indigenous women often had their status, and the status of their children stripped based on marriage to non-Indigenous persons. ${ }^{34}$ As a result, Indigenous women were denied the rights available to men, as they were more vulnerable to losing their status as a registered Indian. This is an example of how Indigenous women have been targets of colonial and assimilationist policies.

The Doctrine of Discovery was used as the legal and moral basis upon which land claims were made to "undiscovered" land, effectively dismissing any sovereign rights Indigenous peoples had. European settlers deemed Indigenous communities as not having any rights to the lands they inhabited, and as such, colonized the land for their monarch to uphold Christianity and spread their religious views. Colonial ideologies are rooted in the assumption that certain identities are not legitimate, and as such, have no claim to land, resources, or titles. Colonialism is therefore seen as a form of domination, either over peoples, groups, territory, behaviour, or resources. ${ }^{35}$ Canada's National Inquiry into Missing and Murdered Indigenous Women and Girls defines colonization as

\footnotetext{
${ }^{31}$ Inter-American Commission on Human Rights. "Missing and Murdered Indigenous Women in British Columbia, Canada." (2014): 24.

${ }^{32}$ Ibid, 39.

${ }^{33}$ Ibid, 23.

${ }^{34}$ Ibid, 23.

${ }^{35}$ Horvath, Ronald J. "A Definition of Colonialism." Current Anthropology 13, no. 1 (1972): 46.
} 
"a [process] by which Indigenous Peoples were dispossessed of their lands and resources, subjected to external control, and targeted for assimilation". ${ }^{36}$ It represents a new reality that was being developed for European settlers, who knowingly created institutions that targeted Indigenous people and discriminated against them. ${ }^{37}$ Colonization is not just the creation of new structures and features of society, but it is also the dismantling and removal of the existing social, political, and cultural organization of life. It is the active removal of existing structures and practices that determine identity and support the life of Indigenous communities.$^{38}$ In the interests of the Crown, colonization serves to overlook the sovereign rights of Indigenous peoples.

A goal of colonization is to ensure the assimilation and erasure of Indigenous peoples in order to uphold the claims to land that European settlers made. Steeped in ideas of racial superiority, Indigenous peoples were cast as less than, and were therefore easily targeted by colonial powers. Indigenous peoples represented barriers to the full control that European monarchs sought, therefore assimilation represented the one way in which the state could obtain the control over land and resources. In 1920, the Deputy Superintendent General of Indian Affairs, Duncan Campbell Scott, wrote: "I want to get rid of the Indian problem...Our objective is to continue until there is not an Indian that has not been absorbed into the body politic, and there is no Indian question, and no Indian Department" ${ }^{39}$ This statement highlights the general sentiment of political elites during the early 1900s; something that was echoed by Prime Minister Sir John A. MacDonald as he envisioned his railway from coast to coast. Lands were to be cleared of Indigenous peoples to make way for European settlers, and for the exploitation of resources for

\footnotetext{
${ }^{36}$ National Inquiry into Missing and Murdered Indigenous Women and Girls [NIMMIWG]. "Reclaiming Power and Place," (2019): 231.

${ }^{37}$ NIMMIWG, (2019): 231.

${ }^{38}$ Ibid, 232.

${ }^{39}$ Joseph, Bob. 21 Things You May Not Know About the Indian Act. Port Coquitlam: Indigenous Relations Press, 2018: 8.
} 
economic gain. Clearing of lands was used as a way to create the reserve system that was a way to further control where and how Indigenous communities are able to move. Mobility remains an important freedom, and cannot be seen as neutral, but rather it is inherently political and unequal. ${ }^{40}$ The Indian Act and the reserve system constrained mobility, and as such, it became easier for Indigenous bodies to experience the intersection of gender, mobility, and violence on the peripheries ${ }^{41}$ Pushing Indigenous peoples to the edges of society has led to issues that continue to be prominent today where land and resources are central to discussions surrounding IndigenousCrown relations. Issues concerning environmental degradation, pipelines, and resource extraction all find themselves rooted in Canada's colonial history and how the state continues to deny Indigenous communities their sovereign land rights.

\footnotetext{
${ }^{40}$ Morton, K. "Hitchhiking and Missing and Murdered Indigenous Women: A Critical Discourse Analysis of Billboards on the Highway of Tears." The Canadian Journal of Sociology, no. 3 (2016): 300.

${ }^{41}$ Ibid, 307.
} 


\section{Missing and Murdered Indigenous Women and Girls}

To further explore Canada's treatment of Indigenous peoples, there is no better example than the gross injustice of the Missing and Murdered Indigenous Women and Girls. This crisis represents decades of violence and discrimination at the hands of the state through the neglect and denial of rights, justice, and security. Practices of colonialism have created the necessary conditions that contribute to the increased marginalization of Indigenous women today. Disproportionate levels of economic and social marginalization result in Indigenous women being placed in precarious, vulnerable situations. These lived realities are marked by systems of power that are designed to disadvantage Indigenous women. The intersectional nature of race and gender paves the way to new forms of violence rooted in a colonial context. All over Canada, First Nations, Métis, and Inuit women are disappearing from their communities at alarming rates. The National Inquiry into Missing and Murdered Indigenous Women and Girls found that Indigenous women are 12 times more likely to go missing and to be murdered compared to other women in Canada in general, and 16 times more likely than White women specifically. ${ }^{42}$ Of all the female homicides in Canada in 1980, 9 percent were Indigenous women; when looking at the same statistic in 2015, Indigenous women represented around 25 percent of homicide victims indicating a big increase ${ }^{43}$ The RCMP have reported that 1,107 of the 6,551 women murdered between 1980 and 2012 were Indigenous women. ${ }^{44}$ While these are numbers that have been reported on, the true number is likely much higher. This is due to a host of issues such as data collection and reporting practices, irregularities in the application of laws, and poor record keeping and follow up of

\footnotetext{
${ }^{42}$ National Inquiry into Missing Murdered Indigenous Women [NIMMIWG]. "Interim Report: Our Women and Girls Are Sacred." (2017): 8.

${ }^{43}$ Ibid, 8 .

${ }^{44}$ Royal Canadian Mounted Police. Missing Murdered Aboriginal Women: A National Operational Overview. (2014).
} 
missing persons reports ${ }^{45}$ However, these numbers also vary by regional contexts. For example, Indigenous women in Manitoba and Saskatchewan are 19 times more likely than White women to be murdered or missing. ${ }^{46}$ Additionally, 55 percent of female homicides in Saskatchewan were Aboriginal women, and 49 percent in Manitoba. ${ }^{47}$ These numbers highlight deep rooted issues regarding the treatment of Indigenous women across Canada. No other group of women experiences this degree of vulnerability and violence, amounting to thousands of women who have been murdered or are missing.

Rooted in oppression and erasure, the Missing and Murdered Indigenous Women and Girls crisis is another manifestation of the state's role in maintaining power. The intersections of being a woman and being Indigenous gives way for a markedly distinct form of discrimination. The reality remains that the killing and disappearances of Indigenous women has become ingrained within existing structures. The state, and state actors such as the RCMP, actively uphold and perpetuate the colonial institutions that were intentionally designed to systematically dispose of Indigenous peoples. Therefore, the violence that is contributing to Missing and Murdered Indigenous Women and Girls, stems from decades of abuse, erasure, and control at the hands of the state.

\footnotetext{
${ }^{45}$ Supra note $28,12$.

${ }^{46}$ NIMMIWG, (2017): 8.

${ }^{47}$ Supra note 36.
} 


\section{Labour Practices of the Extractive Industry}

\section{Canada's Resource Industry at a Glance}

Canada's leading role in natural resources stems from the abundance and diversity of resources within its borders. These resources are both renewable and non-renewable and provide Canada with ample economic opportunity. Renewable resources are naturally replenished, and this includes resources such as wind, solar, geothermal, and hydropower, among others. However, the focus of this paper is to focus on the non-renewable sources such as oil, coal, gas, and nuclear energy. These resources are the basis upon which Canada ranks globally for resource development. There are various forms of extensive oil and gas reserves spread across the country. Canada remains the fifth largest producer of natural gas and the sixth largest producer of oil in the world. ${ }^{48}$ After Venezuela and Saudi Arabia, Canada has the world's third-largest oil reserves, totaling more than 170 billion barrels.$^{49}$ Roughly 96 percent of Canada's oil can be recovered using modern day technology and extraction techniques, ${ }^{50}$ which, depending on the oil consistency, include pump jacks that extend into the earth's surface.$^{51}$ Not only is Canada abundant in oil, but there are also pockets of natural gas notably in British Columbia, Alberta, and offshore in Nova Scotia such as coal, tight gas, and shale gas. ${ }^{52}$ There are a host of new technologies that are utilized to extract natural gases. Although controversial in nature due to the environmental impact, horizontal drilling and hydraulic fracturing of natural gases remains an increasingly common approach.

\footnotetext{
${ }^{48}$ Canadian Association of Petroleum Producers. "Canada's Energy Resources." CAPP. (2018). Retrieved from https://www.capp.ca/canadian-oil-and-natural-gas/canadas-petroleum-resources.

${ }^{49}$ Ibid.

${ }^{50}$ Ibid.

${ }^{51}$ Ibid.

${ }^{52}$ Ibid.
} 
In the fiscal year 2017, Canada's total gross domestic product (GDP) was $\$ 1.653$ billion USD, representing 2.7 percent of the world economy ${ }^{53}$ Of this GDP, the natural resource sector accounted for 17 percent, 4.7 percent of which contributed indirectly and 11.9 percent that was direct..$^{54}$ Of this 11.9 percent was directly contributed by natural resources, 6.9 percent came from the energy sector, 3.6 percent from minerals and metals; and forestry made up 1.4 percent..$^{55}$ The increase in resource development has created a system where dips in resource production has profound impacts on the economy and on national employment levels. Over the next ten years, Canada has 418 major resource projects underway that represents $\$ 585$ billion in investments the largest being in the energy sector with 287 energy projects valued at $\$ 510$ billion. ${ }^{56}$ Beyond the high levels of financial investment and economic dependency, the resource sector in Canada is also responsible for employing 1.82 million jobs, either directly or indirectly. ${ }^{57}$ A total of 14 percent of workers in Canada, have been reported being employed in the resource sector, illustrating the large employment opportunities available. ${ }^{58}$ The capacity in which Canada relies on its natural resources has allowed for the transformation of the Canadian economy, and has created a key reliance that is difficult to break.

\footnotetext{
${ }^{53}$ Trading Economics. "Canada GDP.” Trading Economics. 2018. Retrieved from https://tradingeconomics.com/canada/gdp.

${ }^{54}$ Natural Resources Canada. "10 Key Facts on Canada's Natural Resources.” Government of Canada. August 2018. Retrieved from https://www.nrcan.gc.ca/sites/www.nrcan.gc.ca/files/files/pdf/10_key_facts_NatResources_2018_e.pdf

${ }^{55} \mathrm{Ibid}$.

${ }^{56}$ Ibid

${ }^{57}$ Ibid.

${ }^{58}$ Cross, Philip. "Unearthing the Full Economic Impact of Canada's Natural Resources." Macdonald-Laurier Institute. (2015): 3 .
} 


\section{The Capitalist System}

The need for Canada to continue to take advantage of its resources is due in part to an economic system that is sustained through a constant state of production. A capitalist economic system seeks to increase levels of production for economic gain. Therefore, to understand the intricate relationship Canada has with resources, it is important to understand the basic premise of its economic system. The main aim of capitalism is to maintain a level of supply and demand to generate profit for those who own the mean of production. This is a system that is designed to overlook negative costs to society so long as the producer benefits. ${ }^{59}$ In the Canadian context, the extraction of resources is one example of this constant production for profit. Therefore, there is a trade-off that occurs within this economic system that allows for the generation of wealth to be considered paramount. Basing a system off constant production and wealth generation has created severe issues of inequality that impact vulnerable populations. The dependency on resource extraction makes it difficult to break away from the widespread social and environmental devastation. Given the sheer contribution of the resource industry to Canada's economy, this dependency is crucial. As such, the impact on vulnerable groups such as Indigenous women seems secondary in the broader context of resource extraction. Violence against women, as linked to resource extraction, becomes collateral damage in pursuit of profit maximization within the resource industry.

In Karl Marx's Capital, he put forth the central idea that for a capitalist economy to survive, there must be two classes: the capitalists and the workers they employ ${ }^{60}$ To support this capitalist system there must be a perfect mobility of capital and labour ${ }^{61}$ According to Marx, the capitalist

\footnotetext{
${ }^{59}$ Park, Jonathan T. "Climate Change and Capitalism." Consilience, no. 14 (2015): 190.

${ }^{60}$ Habib, Irfan. "Capital Accumulation and the Exploitation of the 'Unequal' World: Insights from a Debate within Marxism." Social Scientist 31, no. 4 (2003): 4.

${ }^{61}$ Ibid.
} 
mode of production creates wealth through surplus-value, and this capital value depends on a relationship between the producer and hired labour. ${ }^{62}$ Human labour is the source of economic value within a capitalist economy and the one commodity that humans are able to sell to generate both income as hired labour, and profit as employers. ${ }^{63}$ The purchasing of labour power by capitalists is a defining feature of capitalism and is shaped by the social relations between capital and hired labour. ${ }^{64}$ The price of labour power, or wages, is constructed around the means of subsistence, or the necessity of keeping the worker in a working environment to produce. ${ }^{65}$ Therefore, for capitalism to survive, the commodification of labour power must continue. There is an intricate dynamic that has arisen out of the capitalist mode of production that has led to the manifestation of the wage market. The ability to sell labour, to be purchased for the express purpose of production, has configured a market system that depends on maintaining wages for workers. This has allowed for an economic system that needs to constantly purchase labour power to support growth.

Within the context of the resource economy, workers are the means through which wealth is generated and resources are extracted. The introduction of capitalism has led to labour practices that prioritize employing individuals for generating profit over workplace safety. These labour practices are adopted to accommodate the rapid demand and growth in resource extraction to fuel the economy. As such, there is a culture that persists within the resource sector that promotes certain labour practices to maximize profits. Primarily, there are three distinct labour practices

\footnotetext{
${ }^{62} \mathrm{Lu}$, Xiaohe. "Business Ethics and Karl Marx's Theory of Capital - Reflections on Making use of Capital for Developing China's Socialist Market Economy." Journal of Business Ethics 91, no. 1 (2010): 96.

${ }^{63}$ Britannica. "Surplus Value Economics.” Encyclopaedia Britannica. Accessed July 10, 2019. https://www.britannica.com/topic/surplus-value.

${ }^{64}$ Medium. "Karl Marx's 'Wage Labor and Capital”. A Medium Corporation. Retrieved from https://medium.com/@mdowns1611/notes-on-karl-marxs-wage-labor-and-capital-decdc49b566b.

${ }^{65}$ Ibid.
} 
adopted by the resource industry, including the creation of man camps for a mobile workforce; long working days that are high pressure; and excess levels of income, each of which will be discussed in greater detail below. In tandem, these labour practices create conditions that are harmful to communities in resource rich regions. There is a culture associated with these labour practices that has allowed for gender-based violence to increase in resource heavy regions. There is a distinct rigger culture that has manifested in response to demanding labour environments, stemming from high pressure work within a hyper-masculine setting. This hyper-masculine setting normalizes aggressive behaviour, the use of drugs and alcohol, and sex. These labour practices collectively promote a rigger culture, as previously defined, that fosters dangerous social and economic conditions for Indigenous women. This is a culture that is marked with sexist, aggressive rhetoric fueled by the resource sector and its labour system.

\section{Establishing Man Camps}

The first labour condition often created by the resource industry includes the ad hoc housing of workers employed within the resource industry. Man camps, industrial camps, and labour camps are all various names for the same phenomenon of keeping workers in temporary housing. Many of the workers flocking to the region are coming on a temporary basis before they return home during off-seasons. These man camps have arisen as a solution to a housing shortage, and they are associated with the negative implications of what resource development looks like for local communities. In some cases, the influx of workers into the region more than doubles the local population, prompting the need for a quick housing solution. ${ }^{66}$ These camps are owned and operated by the employer and often vary in size and scope of conditions. Some camps are comparable to high-end hotels, others are trailers with shared spaces, and there is often little to no

\footnotetext{
${ }^{66}$ Martin, Carol Muree, Walia, Harsha. “Red Women Rising.” Downtown Eastside Women’s Centre. (2019): 61.
} 
security within these settings. ${ }^{67}$ Moreover, while some provincial labour laws apply to these housing units, there is minimal regulation and monitoring that occurs during off hours ${ }^{68}$ With the creation of these man camps, predominantly male workers are living in proximity to a variety of communities, and in Canada, often near reserves. As of March 2012, there were a total of 1,809 man camps in Northern British Columbia. ${ }^{69}$ While heavily protested, these camps seem to be growing in number with as many as six new camps, housing around 1,000 workers, being proposed in Northern British Columbia around 60 to 100 kilometres from the Nak'azdli Whut'en First Nation community. ${ }^{70}$

These man camps are a frequent practice in resource development as contracted labour living in camps nearby the site maximizes opportunities for resource extraction. While British Columbia currently has many man camps due to the oil and mining business, other resource regions also employ a similar labour tactic. Most notably, the Bakken oil region in North Dakota has jumped to being the second largest oil producing state in the United States with the production of 1.1 million barrels of oil a day, drawing thousands of workers from across the country. ${ }^{71}$ The workers employed on these oil rigs live in sprawling camps that stretch across western North Dakota, Montana, and even into Canada. ${ }^{72}$ Australia is also seeing the use of man camps as a response to a major resource boom. A non-resident workforce has filled resource regions and working camps in both the Pilbara and the Bowen Basin areas; in 2010, there were an estimated 38,340 employees on a working cycle living in quarters, caravan parks, or even motels in Pilbara. ${ }^{73}$

\footnotetext{
${ }^{67} \mathrm{Ibid}, 39$.

${ }^{68}$ Ibid, 39.

${ }^{69}$ Supra note 16, 24.

${ }^{70}$ Morin, Brandi. “Pipeline 'man camps' loom over B .C.'s Highways of Tears.” Canada's National Observer. September 21, 2017.

${ }^{71}$ Supra note 23.

${ }^{72}$ Ibid.

${ }^{73}$ Supra note 21,338 .
} 
Given the nature of the labour practices within the resource sector, man camps alone do not explain why Indigenous women are disproportionately targeted. It is the conditions in which the men work that contributes to the dangerous rigger culture that exacerbates existing inequalities and vulnerabilities.

\section{Creating Demanding Work Conditions}

The second labour practice that contributes to rigger culture is the extremely demanding and high-pressure work atmosphere in resource extraction, which has been described as being similar to a "pressure cooker environment" $\cdot{ }^{74}$ Within a high stress setting, industry workers are constantly pressured to maintain a level flow of resource development. The labour practices of this industry support long working days of countless hours with little room for mistakes. Workers are being challenged with living away from home for prolonged periods of time under difficult working conditions. The long hours, and rotating schedules, coupled with a lack of self-care and apathy in workers, creates highly stressful environments that workers seek to escape, and "blow off steam" ${ }^{75}$ Some industry workers are expected to work for 14 days straight, comprising 12 or more hours per shift, with only 5 or 7 days off in-between, in order to have a continuous stream of production. ${ }^{76}$ One worker candidly described the conditions:

There's a general attitude of 'It's not our problem.' The bigger companies need to get the work done as quickly as possible and however the contractors and sub-contractors do it is up to them. Little attention is paid to how longer shifts at camp (away from family) might physically and mentally affect a worker. It's considered a worker's choice and responsibility. ${ }^{77}$

As a result, there is a culture that is created where the men working within the sector are experiencing burn out. The physical, mental, and emotional toll of working under these conditions,

\footnotetext{
${ }^{74}$ Supra note $25,44$.

${ }^{75}$ Supra note 16.

${ }^{76}$ Supra note 21, 338.

${ }^{77}$ Supra note 16, 26.
} 
coupled with a culture of apathy and lack of self-care has led to workers needing to break away from reality. This rigger culture promotes a party atmosphere due to the way workers "loosen up" after block shifts. The mix of drugs and alcohol, along with desire to engage in sex, has allowed for workers to "blow off steam" in a manner that can be harmful. This behaviour is rooted in the unique rigger culture that has created ties between masculinity, drugs and alcohol, and engaging in aggressive non-consensual sexual behaviour that devalues women - all of which represent a dangerous situation for women in the community as it begins bringing sexist attitudes into the mix. The problematic use of substances has created the conditions that lead to increased occurrences of gender-based violence.

To cope with the burnout that workers are feeling within these settings, many blow off steam in harmful ways. An anonymous worker on an industrial camp articulated the following:

"'Blowing off steam' is about experiencing freedom from very restrictive safety regulations. Suddenly, you can do whatever you want without fear of losing your livelihood. For example, on your days off, you don't really have the right to speed, but there is a sense of freedom, so you do it." 78

There is a sense of freedom and lashing out that occurs when these workers have free time off of work. The labour practices of the industry aim to prioritize making money for the companies, ensuring they are meeting production goals. This has come at a risk for many workers as they then turn to dangerous and reckless behaviour to compensate for the controlling environment in which they live and breathe during resource booms. Oil patch culture was described by someone whose partner is an oil worker as being " $[\mathrm{h}]$ ow hard you work, how much you party, and how many toys you have..." ${ }^{79}$ Rigger culture has come as a response to the highly demanding work settings within the resource sector, as it promotes a way to relax and take back control of their actions. However,

\footnotetext{
${ }^{78} \mathrm{Ibid}, 26$.

${ }^{79}$ Supra note $24,44$.
} 
this control has come at a price for Indigenous women as they are exposed to the workers' party attitude and carefree behaviour.

\section{Providing Excess Income}

The third, and last, labour practice the industry employs that facilitates instances of genderbased violence is the excess levels of income circulating within resource-rich areas. The level of pay for resource industry workers typically exceeds the incomes of those who live in the region permanently. These jobs are characterized by quick money, as it becomes the primary reason why non-resident workers are attracted to the sector. ${ }^{80}$ Being away from home with disposable amounts of income encourages reckless spending on drugs and alcohol. Amnesty International found that the free flow of money within in a resource region gets exploited by drug dealers who move into the area to provide illicit narcotics for a workforce that is primarily young males.$^{81}$ One young man working as a teenager in the industry recounts coming from camp with "thousands of dollars in his pocket" and not knowing how to manage that wealth. ${ }^{82}$ The combination of being lonely and earning high wages has resulted in workers spending that money on drugs, alcohol, and purchasing sexual services, among other things. This widespread phenomenon of resource money has riddled North Dakota with crime and drugs. Timothy Q. Purdon, the United States Attorney for North Dakota stated that "more money and more people equals crime" ${ }^{83}$ highlighting the impact of high wages on resource communities. While having disposable income increases spending on drugs and alcohol, it can also heighten economic inequality.

\footnotetext{
${ }^{80}$ Laboucan-Massimo, Melina. "Climate Justice Must Include Gender Justice,” David Suzuki Foundation. (2018). Retrieved from https://davidsuzuki.org/story/climate-justice-must-include-gender-justice/.

${ }^{81}$ Supra note 25, 39.

${ }^{82}$ Ibid, 39.

${ }^{83}$ Supra note 22.
} 
An increase in violent crime and drug use stems from the free flow of money within resource boom towns. The movement of highly paid resource workers into a resource region living in various camps, with limited freedom and spending opportunities has given rise to a crime wave. ${ }^{84}$ The chief judge at the Mandan, Hidatsa and Arikara Nation, Diane Johnson, noted that with the oil boom in North Dakota for the last two years, crime has tripled in the region with 90 percent being drug-related. ${ }^{85}$ With excess money in flow, it attracts various gangs trying to facilitate their drug trade by targeting young male workers. The presence of extractive projects in communities has been found to increase substance abuse as disposable income means more access to drugs and alcohol ${ }^{86}$ Looking closer to home, one can look to the Fort St. John area that has some of the highest drug and alcohol rates in British Columbia ${ }^{87}$ With a heavy resource industry in Northern British Columbia, 87 percent of man camps are located near Fort St. John. ${ }^{88}$ Through The Peace Project that looked at violence against women and girls in Fort St. John, it was found that the area is home to a heavy party atmosphere where new workers get pulled into the drug scene by older workers, sometimes going on drug and alcohol binges.$^{89}$ Further, this study also found that drugs and alcohol are considered the main contributor to violence against local women. ${ }^{90}$ Part of this is due to the social norms around bars and clubs as the main place where workers go to blow off steam after work. These social gatherings lead to drug or alcohol induced crimes, with higher

\footnotetext{
${ }^{84}$ Supra note 22.

${ }^{85}$ Ibid.

${ }^{86}$ Koutouki, K., Lofts, K., \& Davidian, G. “A rights-based approach to indigenous women and gender inequities in resource development in northern Canada." Review of European, Comparative \& International Environmental Law, 27 (2018): 66.

${ }^{87}$ Supra note $15,6$.

${ }^{88}$ Ibid, 24.

${ }^{89}$ Ibid, 24.

${ }^{90}$ Ibid, 102.
} 
incidents of conflict and sexual assault. ${ }^{91}$ Disposable amounts of income has led to the accessibility of drugs and alcohol, and a partying culture marked by violence.

The existing economic disparity between Indigenous women and non-Indigenous men increases when extractive projects commence within a region. This is due to the fact that these types of jobs are predominantly accessible by men, leaving women struggling. The sector discriminates against women as recruitment and employment practices are targeted towards men, seeing women as unsuitable for manual intensive labour. ${ }^{92}$ The highly lucrative resource sector raises costs of living in the region, creating an income gap for those who have access to resource jobs versus those who do not. Further, this income gap that is most often felt by women, makes basic necessities, such as housing, expensive and inaccessible.

For Indigenous women who are disproportionately impacted by economic insecurity, the resource sector and rising costs of living forces them to work longer, farther from home, and resorting to precarious work to earn an income..$^{93}$ Therefore, while economic insecurity remains a gendered issue, the resource sector simply contributes to existing forms of inequality. The resource sector's high wages are reflective of gendered norms, and tying gender to income facilitates a sinister culture rooted in sexism. The rigger culture of the extractive industry rewards making fast, quick money, and justifies the spending of that money in ways that negatively impact women. Whether that is through spending income on drugs and alcohol, or engaging in disrespectful behaviour while purchasing sexual services, it is apparent that the high level of income is an issue within the sector. The dominance that is associated with earning lots of money stems from hypermasculine notions cultivated by a rigger culture.

\footnotetext{
${ }^{91}$ Supra note $17,10$.

${ }^{92}$ Oxfam International, "Position Paper on Gender Justice and the Extractive Industries,” March 2017, 4.

${ }^{93}$ Ibid, 6 .
} 


\section{Rigger Culture as Gender-Based Violence}

Workers within the sector are exposed to a culture that defines its members by the heavy use of drugs and alcohol, partying, sex, and various forms of crime and violence. The connection between masculinity, apathy, sexism, and resource extraction has created an identity for workers that have a negative gendered impact on Indigenous women. Existing forms of socioeconomic and political marginalization become exacerbated when a male-dominated workforce engages in destructive behaviour, further perpetuating vulnerable situations for Indigenous women. The propagation of a system rooted in capitalism has successfully recreated historical forms of colonial violence, as resource extraction continues to value resources over the lives of Indigenous women.

The influx of a large, transient workforce into a region has increased the risk for women as men are statistically more likely to be perpetrators of violent crime. ${ }^{94}$ The presence of men in a region alone cannot explain the gender-based violence that ensues within resource communities, but it should be understood as a culture of norms that foster and sustain forms of violence that Indigenous women face. A female worker within the sector described the work environment as a "boys club" that sees harmful attitudes become the norm. ${ }^{95}$ This culture is dominated by a sexist rhetoric that devalues women, and is unaccepting of diversity in general.${ }^{96} \mathrm{~A}$ study conducted by Kassandra Landry on the Alberta oil industry found that sexist views of women are expressed regularly by oil workers, and is part of the "oil culture" they both helped to create and are embedded within. ${ }^{97}$ However, when looking at man camps, working conditions, and excess income that creates a rigger culture, there are distinct outcomes that allow Indigenous women to be

\footnotetext{
${ }^{94}$ Supra note $24,4$.

95 Ibid, 42.

${ }^{96}$ Landry, Kassandra. “'Camp Syndrome?' Exploring Frontier Masculinity in Alberta’s Oil Production Culture: Oil Worker and Sex Worker Perspectives.” MA Thesis, University of Alberta, 2017: 66.

${ }^{97}$ Landry, Kassandra, 2017: 67.
} 
subjected to gender-based violence. The fostering of a rigger culture through certain labour practices has increased crime, the use of drugs and alcohol, and the purchasing of sexual services. Collectively, these characteristics of a resource culture has led to Indigenous women being at the receiving end of various forms of violence.

But why are Indigenous women and girls disproportionately impacted by this? The truth is that historical forms of colonial oppression and denial of political, social, and economic freedoms has resulted in Indigenous women experiencing vulnerabilities in many facets of their life. First Nation, Métis, and Inuit women are pushed to the peripheries of society with little resources to be able to break out of the cycle of poverty. This leads to Indigenous women needing to take on precarious employment to provide for themselves and their families. The economic, social, and political marginalization that Indigenous women must navigate is something known as "risk pile up. ${ }^{\prime 98}$ This concept refers to the idea that the addition of new pressures from extractive industries paves the way for new forms of risks and vulnerabilities. ${ }^{99}$ There is a distinct lived reality that comes from being a woman, being Indigenous, and living within resource regions. These intersecting identities has led to new forms of discrimination, and maltreatment. With Indigenous women being accessible to these workers due to existing forms of injustices, they become the target of their drunken incidents, and exposed to forms of violence. The increases in violent crimes and aggravated assaults, coupled with sexist beliefs that workers have towards Indigenous women, results in gender-based violence. As Indigenous women are pushed into vulnerable situations, the continued and added exposure to dangerous circumstances results in severe consequences.

\footnotetext{
${ }^{98}$ Supra note $12,7$.

${ }^{99}$ Ibid, 7.
} 
Mia, a First Nation woman in Alberta, was on call 23 hours a day when she was engaged in sex work in Fort McMurray during the oil sands boom. ${ }^{100}$ Finding herself in the midst of numerous dangerous situations, Mia is haunted by her past and the men she interacted with. She recollects having a client who threatened to hang her in his apartment when not consenting to certain sexual acts. ${ }^{101}$ She describes that "the guys are maybe lonely...they're away from home, they have a lot of money - disposable income if you will." ${ }^{102}$ She goes on to describe the oil environment as "gross" and that "men are everywhere looking at women like they're meat..." This illustrates the all too normal behaviour, and treatment, that Indigenous women must endure within the resource industry. Many studies, reports, and lived experiences have shown that demand for sex work rises in resource development areas for a number of reasons ${ }^{104}$ These reasons include the presence of a transient male workforce living away from home, excess amounts of income, and lack of community ties. Not only are there increases in the purchasing of sex, but there are also increased levels of domestic violence, sexually transmitted infections, HIV/AIDS, sexual assault and rape, substance use, and sex trafficking. ${ }^{105}$ There has become a predictability to the sex crimes, sex trade, and violence that are by-products of gas, oil, and mining projects. The change in demographics due to an influx of men into the region creates an imbalance in the sex ratio of the population. This promotes certain types of dynamics, potentially opening the door to crimes against women, and increased sexual assaults. ${ }^{106}$

\footnotetext{
${ }^{100}$ Supra note 1.

${ }^{101}$ Ibid.

102 Ibid.

103 Ibid.

${ }^{104}$ Supra note $24,49$.

${ }^{105}$ Supra note 12,8 .

${ }^{106}$ Supra note $17,11$.
} 
Sexual violence within the resource industry is most notable in Fort St. John, British Columbia as it has become the epicentre of experiences involving sexual assault and missing Indigenous women. There is a notable young, male population living within the Fort St. John area; of those aged 20 to 64 years, there are approximately 27.6 percent more males than females. ${ }^{107} \mathrm{In}$ 2017, this little city's sexual assault rate was 100.01 per 100,000 people, almost double the national average of 56.56 per $100,000 \cdot{ }^{108}$ Not only is the sexual assault rate high, but the rate of physical assaults in Fort St. John is more than twice the national average as well. ${ }^{109}$ These spikes in both sexual assault and physical assault in are reflective of the impact of extractive projects on local communities. The rigger culture that comes out of resource extraction has created the exact conditions needed for sexual assault and gender-based violence to foster. The mix of frontier masculinity, restrictive work environments, drugs and alcohol have increased the chances of Indigenous women being victims of sexual violence.

The Watson women, an Indigenous family living in Northern British Columbia, have all worked within industrial camps and have all experienced instances of sexual assault or harassment. Dating back to the 1960s during the construction of the Bennet Dam, Marvelene Watson was subjected to rampant racism and abuse. ${ }^{110}$ Tammy Watson, one of Marvelene's daughter, recalls growing up and being abused by her father's friends who were all transient workers at various projects. ${ }^{111}$ Another Watson daughter, Ashley, was been sexually harassed in a number of camps across Northern British Columbia in 2015 and 2016. ${ }^{112}$ Recounting the experiences of these women serves to highlight how pervasive this pattern of sexual violence has become, as well as how long

\footnotetext{
${ }^{107}$ Supra note $15,7$.

${ }^{108}$ Supra note 3.

${ }^{109}$ Ibid.

${ }^{110}$ Ibid.

${ }^{111}$ Ibid.

${ }^{112}$ Ibid.
} 
this has been happening. These social implications of resource extraction are rooted deep in Canada's history and has nestled itself into the fabric of what it means to be a resource country.

Many healthcare workers within these communities see first-hand the destruction and impact that resource projects bring with them. Liza Sam who works as a nurse in north-central British Columbia has had men stop her by Nak'azdli gas stations to ask, "where they can pick up women." ${ }^{113}$ There is a culture amongst resource workers that view women as objects, a series of trophies to be collected as a testament to their masculinity. This attitude has led to numerous health concerns as well, as health centres have noted the spread of STIs in Nak'azdli Whut'en, a First nation community, and the need to assemble rape kits as a response to expanding resource development projects and protect Indigenous women.

Indigenous communities suffer from systemic inequities that leave them without adequate access to supports and services that would reduce violence. Lack of supports has led to a strain on local health services that perpetuates a cycle of violence. This is best illustrated through the threeweek hunger strike taken by the Executive Director of a women's shelter in Fort McMurray, Alberta inn 2010. The strike was to shed light on the desperate conditions, and lack of resources to respond to the need of the region during the oil boom. ${ }^{114}$ Fort McMurray has seen a dramatic increase in sexually transmitted diseases and increasing sex work. ${ }^{115}$ The communities that are facing high levels of sexualized violence due to the rigger culture are not equipped to deal with the normalization of this behaviour. As a result, there needs to be a shift in attitudes and practices that serve to look at the bigger picture of Indigenous women and their relationship to resource extraction and the land.

\footnotetext{
${ }^{113} \mathrm{Ibid}$.

${ }^{114}$ Adamson, Rebecca. "Vulnerabilities of Women in Extractive Industries," Indian Journal of Women and Social Change 2, no. 1 (2017): 25.

${ }^{115}$ Adamson, Rebecca. (2017): 25.
} 


\section{Policy Recommendations}

The answer to the complex relationship between resource extraction and gendered violence is not simple. Similar to the way that Indigenous women experience compounding forms of inequality, the appropriate way to address this injustice must also come in various forms. In order to respond to the rigger culture that fosters aggressive, hyper-masculine behavior, there must be a dismantling of colonial processes that uphold systems of racist and sexist. The existing capitalist structure that continues to value profit generation over the lives of Indigenous women has created dangerous conditions. Thus, appropriate responses must look at the deeply entrenched sexism within Canada's resource sector. There must be a movement toward transformative change that looks to bring the interests Indigenous peoples to the forefront of Canada's resource economy. Any sort of policy in this realm must attempt to reduce instances of gender-based violence, increase regulations within the sector, better working conditions within man camps, improve supports and services, and allow for Free, Prior and Informed Consent.

\section{Improve Sector Regulation}

To address the labour practices within the resource industry, and particularly surrounding the existence of man camps, there needs to be an improvement and increase in regulations. Although Alberta and British Columbia have regulations for "Work Camps" and "Industrial Camps," these regulations fall short of addressing gender-based violence. The need for accountability in the sector is evident by the rampant crime, drugs, and abuse that ensues as large numbers of male workers move into a region. To govern work camps in Alberta, there is a set of provincial regulations titled Work Camp Regulations that address a whole host of issues such as location, furnishings, garbage, water, laundry, and compliance ${ }^{116}$ Likewise, the British Columbia

\footnotetext{
${ }^{116}$ Work Camps Regulation, Alberta Regulation 218/2002. http://www.qp.alberta.ca/documents/Regs/2002_218.pdf.
} 
Industrial Camps Regulations address construction, operation, and abandoning camps. ${ }^{117}$ The existing regulations illustrate the extent to which provinces are thinking about these camps, however there is little within these regulations that address the social implications. By and large, provincial regulations address issues for the operator, and the end user of the camps who are the workers. In order to reduce instances of gender-based violence and increase accountability, resource companies need to play a greater role at managing their workers and the culture they foster within their work environments. The turning of a blind eye to the actions of transient workers further encourages the same behavior that is creating violent conditions for Indigenous women and nearby communities. The two Alberta and British Columbia regulations represent existing documents that can be used to regulate the sector. Adding sections on violence and workplace behavior could provide a framework for addressing it. There is a need to regulate the workers in a manner that shifts the culture; going from highly restrictive to an environment of inclusivity and zero tolerance.

The introduction of regulations aimed at reducing violence must be brought to the forefront of policy agendas. Resource companies across the country are regulated for a variety of measures, including ownership, production, distribution and more. What is needed is for companies and provincial counterparts to address the ongoing violence stemming from development projects. This can be done by reinforcing professional conduct, discouraging aggressive and sexist rhetoric, and having a greater responsibility to the communities in which they are operating. This could look like adopting specific work policies that outline appropriate behavior, alongside a consequence for non-compliance. With the amount of power and consolidation of wealth held by resource

\footnotetext{
${ }^{117}$ Industrial Camps Regulations, B.C. Reg. 70/2012. http://www.bclaws.ca/civix/document/id/loo99/loo99/70_2012.
} 
companies, there is an obligation to provide redress to the communities they are affecting. By acknowledging their part in the ongoing sexual, physical, and mental violence, there are opportunities to better the system. However, this cannot happen until there is a fundamental shift in the culture of the resource sector towards one of respect for the land, the community, and of women.

In order to look at the culture of work camps and of the resource sector, the conditions within these camps must also be improved. Intensive and demanding work conditions have fostered a rigger culture that is leading to increased instances of violence. There is a need to improve the working environment in an attempt to curb the dangerous behavior that exists. An example of this is to change the block shifts that workers are often expected to work. By loosening the working hours, reducing number of shifts, increasing breaks between shifts, and imposing maximum working hours, a difference can be made in how workers feel. By taking away feelings of being burnout, overworked, loneliness, and stress, companies have the ability to shape how their employees behave when they go home. Perhaps they will not need to turn to excessive use of alcohol and drugs to blow off steam. Mandating a change in working hours creates accountability within the employers and addresses the underlying cause of violent behavior. For non-compliance, operators could be subjected to provincial inspections, or fines as a way to ensure employers are serious. Another way to deter harmful behavior is to reduce the consumption of drugs through means such as random drug tests while working and operating machinery. By discouraging excessive use of drugs and alcohol, it is possible to take away the things that have been identified as exacerbating gender-based violence. 


\section{$\underline{\text { Increase Supports and Services }}$}

There is also a dire need for an increase in local supports and services for women in resource regions. As evident by the hunger strike taken by the Executive Director of Fort McMurray's women's shelter, there are a lack of resources in the affected communities. According to the shelter, during the 2009 oil boom, they turned away 400 women and the children they may have brought with them ${ }^{118}$ essentially forcing them to return to the abusive conditions from which they fled. This exemplifies the urgency to increase accessibility to resources that are so desperately needed. By increasing supports to shelters, health centers, and resource centers, these organizations are able to address the underlying conditions that force women into vulnerable situations. For example, increasing the number of beds in shelters would keep Indigenous women off the streets and away from precarious forms of housing that increases vulnerability to forms of violence. However, this requires a coordinated effort from all levels of government, a flow of funding, and mechanisms of accountability. By increasing access for Indigenous women, they are able to have a level of safety, and security. Providing women with the appropriate tools to navigate a system that entrenches economic, social, and political marginalization will allow for empowerment, and a reduction of gender-based discrimination. Through the ratification of the United Nations' Beijing Platform for Action, the Government of Canada has committed to conducting a Gender Based Analysis (GBA+) for policies, programs and initiatives ${ }^{119}$ This commitment is rooted within the basic idea that women have a markedly different experience than that of the average individual. This means providing women with the right tools and resources to address the manner in which

\footnotetext{
${ }^{118}$ Wingrove, Josh. "Hunger strikers seek money for women's shelter in Fort McMurray." The Globe and Mail. August 2010. Retrieved from https://www.theglobeandmail.com/news/national/hunger-strikers-seek-money-forwomens-shelter-in-fort-mcmurray/article1377238/.

${ }^{119}$ Status of Women Canada. "What is GBA+?". Government of Canada. Retrieved from https://cfc-swc.gc.ca/gbaacs/index-en.html.
} 
they experience policies, programs and initiatives. However, this GBA+ must be legally mandated, and occur across federal ministries and agencies to make a difference. This analysis can be conducted on potential development projects before approvals are given, and before corporations have begun their business.

Part of this increase in resources includes education, training, and equal opportunities to employment. Incentivizing education can occur through the adoption of the Calls to Action outlined in the Truth and Reconciliation Commission of Canada, 2015 (TRC). The TRC has called upon the federal government to draft new Aboriginal education legislation with informed consent and participation of Indigenous peoples to close educational gaps, improve levels of educational attainment, develop culturally appropriate curriculum, and providing adequate funding to reach these end goals. ${ }^{120}$ By helping Indigenous women get an education, jobs, and escape economic insecurity, it reduces the dependency on abusive relationships, precarious employment, and various vulnerable situations. Having well-paying, stable jobs, and education would empower Indigenous women to navigate a colonial system that disadvantages them at every turn. It returns agency to Indigenous women to then seek out opportunities that would reduce instances of genderbased violence. By breaking the cycle of poverty, increasing supports, returning agency, and reducing inequality, Indigenous women and their communities are able to fight back against powerful companies that seek to exploit their lands and bodies. However, this must be an undertaking by the federal government to shift the status quo and close gaps in education and funding. Incentivizing companies to employ Indigenous peoples, provide skills training, and promoting Indigenous peoples to higher ranks will aid in visibility, strengthen key relations, and

\footnotetext{
${ }^{120}$ Truth and Reconciliation Commission of Canada. "Truth and Reconciliation Commission of Canada: Calls to Action.” TRCC. 2015. Retrieved from http://nctr.ca/assets/reports/Calls to Action English2.pdf.
} 
address economic and social challenges. By providing the proper supports, there can be an enhancing of resiliency that would help in reducing instances of violence. However, this resiliency must come in conjunction with broader change in systems and moving towards decolonization and reconciliation.

\section{Ensure Free, Prior, and Informed Consent}

The reconciliation that is needed stems from a fundamental issue: Indigenous communities are denied their lands and participation in decision making processes. In order to move towards a future of reconciliation and self-determination, there needs to be a place for First Nation, Métis, and Inuit leadership. Part of this is engaging in the appropriate consultation with communities on matters that inherently impact them. The concept for Free, Prior and Informed Consent (FPIC) is an inherent right that helps to ensure survival, dignity, and well-being of communities. ${ }^{121}$ It is about Indigenous peoples right to self-determination, good relations, dialogue, understanding, mutual respect, and ensuring that communities benefit from activities carried out on their lands. ${ }^{122}$ The purpose of this dialogue is to mitigate environmental and social impacts on Indigenous communities. This concept is crucial in resource development in Canada, and should be adopted when looking to any extraction projects. Article 32 of The Declaration on the Rights of Indigenous Peoples requires that consultation needs to be had for projects including mining or exploitation of resources. ${ }^{123}$ By engaging in consultation with Indigenous communities on resource development projects, FPIC creates a space to address the potential for impact. This includes taking into account the gendered implications of extraction on Indigenous lands or near their communities. Ensuring

\footnotetext{
${ }^{121}$ Kairos Canada. "Free, Prior \& Informed Consent." Kairos Canada. 2019. Retrieved from https://www.kairoscanada.org/what-we-do/indigenous-rights/free-prior-informed-consent. 
Indigenous stakeholders are informed, and part of the consultation process, it allows for a collaborative decision-making process.

Putting Indigenous voices and women at the forefront of these processes would help to address the ongoing social implications of resource projects. Governments, organizations, and corporations have a duty to consult the relevant groups to ensure that land, resources, culture and community are being respected. By allowing Indigenous modes of assessment of a project, these communities have a say in how their lives and rights are being affected. For example, in March of 2011 the federal government released updated consultation guidelines that defined the "highest obligation of government as 'possible accommodation' even in cases of 'irreversible impact' on an 'established' right." ${ }^{124}$ Releasing guidelines for how to consult with Indigenous groups imposes a duty upon the Government of Canada. An example of meaningful consultation is meeting with Indigenous groups to discuss implications of a proposed project, including a veto clause, or working towards operational plans that address how to come to a middle ground to move forward in way that is mutually beneficial and respectful.

As has been discussed, the impact of resource extraction on Indigenous women is problematic, and has created the conditions for physical, sexual, and emotional violence. With having an informed consultation process, accountability and respect can be restored into the sector. Resource companies, and various levels of government can work with Indigenous counterparts to ensure they reach a conclusion that puts the interests and lives of Indigenous women first. Using a gendered lens to resource development projects will ensure equality, as well as making sure all stakeholders are on the same page. The history of colonialism has othered Indigenous peoples in

\footnotetext{
${ }^{124}$ Aboriginal Affairs and Northern Development Canada. "Aboriginal Consultation and Accommodation - Updated Guidelines for Federal Officials to Fulfill the Duty to Consult". March 2011, 5.
} 
this country, and in order to reconcile the decades of erasure and cultural genocide, it is imperative to return to what was taken away from them: their self-determination. 


\section{Conclusion}

The intersecting side effects of resource extraction in Canada has exacerbated existing realities for Indigenous women. Colonial systems have pushed First Nations, Métis, and Inuit women into vulnerable situations that put them into disproportionate contact with many of the problematic aspects of the extractive industry. Through a system that seeks to deny Indigenous peoples their rights, lands, and freedom, Indigenous women are forced into dangerous situations. Widespread policies of assimilation and discrimination have had long lasting impacts on generation of Indigenous families. For example, financial insecurity has given rise to precarious forms of employment, such as sex work, bartending, self-employed jobs, home-based workers, and within the resource industry itself. When Indigenous women are overrepresented in these categories, the rise of drugs, alcohol, purchasing of sex, and crime have an invariable impact on them. This gender-based discrimination has led to Indigenous women bearing the brunt of the social ills associated with resource extraction. Further, the resource industry profits from visible minorities maintaining their low socioeconomic status. The notion that women are expected to be available for men, and part of how workers exhibit their masculinity, has created a relationship between resource extraction and gender-based violence. To maintain levels of resource extraction, men are encouraged to "blow off steam" through aggressive, hyper-masculine behaviour. This includes going on drug binges, purchasing sex, engaging in crime, and more. As a result, Indigenous women have become a central component of generating wealth for resource corporations. The industry is dependent on sustaining a certain level of gender-based violence to facilitate the whole system and fuel Canada's economy. 
The inescapable fact is that the existing dependency on resource extraction has gendered implications for Canada. Capitalist structures rooted in a system of constant production has sought to overlook the social implications of resource development projects. The fact that Indigenous women are overrepresented in categories such as poverty, homelessness, rates of assault, unemployment, and more speaks volumes about Canada's existing system. Compounded with violence against the land, these issues are heightened, leading to gender-based violence. There is a distinct rigger culture that has severe ramifications on vulnerable segments of society. The industry as a whole has put forth a labour system that creates this aggressive culture. Further, this system and culture seeks to maintain power relations in a colonial state. Decades of erasure has served to disempower Canada's Indigenous peoples, capitalizing on their loss of identity and voices. Resource extraction has taken advantage of a colonial history, loss of land, and gender inequities. The gender-based violence that ensues once a resource development project has begun is an extension of colonial domination and control which further entrenches systems of power. In order to address these systemic, long-standing issues, there must be efforts that move towards returning power and rights and turning to empowering partnerships and reconciliation.

To conclude, it is apparent that Canada's mode of resource production has taken advantage of its colonial history. The resource economy in Canada hinges on denying Indigenous women their rights, lands, safety and security. Through the labour practices of the resource sector, there is an alarming rigger culture that has taken over the work environment that employs around 14 percent of Canadians. The combination of man camps, highly restrictive work environments, and excess income has created a reality for Indigenous women that is hard to escape. There is a dark side to the resource sector, and a transient workforce that operates from within the shadows. As a culture of hyper-masculinity is developed, there becomes a pattern of behaviour that coincides 
with this culture. These behaviours are rooted in an industry that seeks to prioritize economic gain over the negative implications it brings. From workers exhibiting sexist, aggressive behaviour to consuming drugs, committing crimes, and suffering from highly stressful work environments, this industry pushes its workers over the edge. Caught in the midst of this rigger culture, are Indigenous women who experience the violence on the land through their bodies. By way of the gender-based violence that ensues in resource regions, it is apparent that the sector has wide sweeping implications. The increase in physical and sexual assault, crimes, and substance use has created problematic conditions that amplify the existing forms of inequality that Indigenous women face. However, Canada has signaled that it values the economic gain from exploiting lands, more than the exploitation of its women.

The extraction of resources, both in active projects and proposed projects, has devastating consequences for nearby communities. But the denial of such devastation has worsened the violence, brushing it aside and continuing to invest in resource extraction. What is required to end this violence against First Nations, Métis, and Inuit women is a movement towards transforming the resource economy, decolonization, and returning the rights of Indigenous peoples. Without making strides towards the systems of power that undermine Indigenous peoples, the continued violence on the land will invariably have a gendered impact. What faces Canada going forward is a choice between profit and protecting Indigenous women. With the world watching how Canada is failing to support the agency of Indigenous women, the next step is to make changes to how natural resources are exploited. Without ceasing the violence on the land, the violence on Indigenous bodies will continue as it has for decades under a colonial system. 


\section{References}

Aboriginal Affairs and Northern Development Canada. "Aboriginal Consultation and Accommodation - Updated Guidelines for Federal Officials to Fulfill the Duty to Consult". March 2011, 5.

Adamson, Rebecca. "Vulnerabilities of Women in Extractive Industries," Indian Journal of Women and Social Change 2, no. 1 (2017): 24 - 31.

Amnesty International. "Out of Sight, Out of Mind: Gender, Indigenous Rights, And Energy Development in Northeast British Columbia, Canada." (2016). Retrieved from https://www.amnesty.ca/sites/amnesty/files/Out\%20of\%20Sight\%200ut\%20of\%20Mind \%20EN\%20FINAL\%20web.pdf.

Arneil, Barbara. "Domestic Colonies in Canada: Rethinking the Definition of Colony." Canadian Journal of Political Science 51, no. 3 (2018): 497519, http://resolver.scholarsportal.info/resolve/00084239/v51i0003/497_dcicrtdoc.

Assembly of First Nations. “Dismantling the Doctrine of Discovery”, January 2018. Retrieved from https://www .afn.ca/wp-content/uploads/2018/02/18-01-22-Dismantling-theDoctrine-of-Discovery-EN.pdf.

Britannica. “Surplus Value Economics.” Encyclopaedia Britannica. Accessed July 10, 2019. https://www.britannica.com/topic/surplus-value.

Canadian Environmental Assessment Act (2012, c. 19, s. 52). Retrieved from the Justice Laws website: https://laws-lois.justice.gc.ca/PDF/C-15.21.pdf

Caraher, William R., Bret Weber, Kostis Kourelis, and Richard Rothaus. "The North Dakota Man Camp Project: The Archaeology of Home in the Bakken Oil Fields." Historical Archaeology 50, no. 2 (2017): 267-87. doi:10.1007/s41636-017-0020-8.

Cross, Philip. "Unearthing the Full Economic Impact of Canada's Natural Resources." Macdonald-Laurier Institute. (2015): 1-35. Retrieved from https://www.macdonaldlaurier.ca/files/pdf/MLI-CrossNaturalResourcesPaper05-15WebReady.pdf.

Carrington, K., Hogg, R., \& McIntosh, A. “The resource boom's underbelly: Criminological impacts of mining development." Australian \& New Zealand Journal of Criminology, 44, no. 3 (2011), 335-354. https://doi.org/10.1177/0004865811419068

Deller SC, Deller MA. "Rural crime and social capital." Growth Change, 41, no. 2 (2010): 221275.

Edwards, Kyle. “How we treat women”. Macleans, May 13, 2019.

https://www.macleans.ca/how-we-treat-women/. 
Eckford, Clarice and Jillian Wagg. 2015. "The Peace Project: Gender Based Analysis of Violence against Women and Girls in Fort St. John." Fort St. John Women's Resource Society. (2017). https://thepeaceprojectfsj.files.wordpress.com/2014/03/the_peace_project_gender_based analysis amended.pdf.

Encyclopedia. "Resource Extraction." (2016). Retrieved from https://www.encyclopedia.com/environment/energy-government-and-defensemagazines/resource-extraction.

Gibson, G., K. Yung, L. Chisholm, and H. Quinn with Lake Babine Nation and Nak'azdli Whut'en. "Indigenous Communities and Industrial Camps: Promoting healthy communities in settings of industrial change." (2017). http://www.thefirelightgroup.com/firelightmaterials/wpcontent/uploads/2016/03/Firelight-work-camps-Feb-8-2017 FINAL.pdf.

Habib, Irfan. "Capital Accumulation and the Exploitation of the 'Unequal' World: Insights from a Debate within Marxism." Social Scientist 31, no. 4 (2003): 3-26. doi:10.2307/3520264.

Horvath, Ronald J. "A Definition of Colonialism." Current Anthropology 13, no. 1 (1972): 4557. http://www.jstor.org/stable/2741072.

Horwitz, Sari. "Dark Side of the Boom.” The Washington Post, September 28, 2014. https:/www.washingtonpost.com/sf/national/2014/09/28/dark-side-of-theboom/?noredirect=on\&utm_term $=. f d 282807 \mathrm{cfcc}$.

Indian Act (1985, R.S.C., c. I-5). Retrieved from the Justice Laws website: https://lawslois.justice.gc.ca/PDF/I-5.pdf.

Industrial Camps Regulations, B.C. Reg. 70/2012. http://www.bclaws.ca/civix/document/id/loo99/loo99/70 2012.

Inter-American Commission on Human Rights. "Indigenous Women and Their Human Rights in the Americas.” (2017). Retrieved from https://www.iwgia.org/images/documents/popular-publications/indigenous-womenamericas.pdf.

Inter-American Commission on Human Rights. "Missing and Murdered Indigenous Women in British Columbia, Canada." (2014). Retrieved from http://www .oas.org/en/iachr/reports/pdfs/indigenous-women-bc-canada-en.pdf.

Joseph, Bob. 21 Things You May Not Know About the Indian Act. Port Coquitlam: Indigenous Relations Press, 2018. 
Kairos Canada. “Free, Prior \& Informed Consent.” Kairos Canada. 2019. Retrieved from https://www.kairoscanada.org/what-we-do/indigenous-rights/free-prior-informedconsent.

Komarek, T.M. "Crime and natural resource booms: evidence from unconventional natural gas production.” Ann Reg Sci, 61 (2018): 113-137. doi: 10.1007/s00168-018-0861-x.

Koutouki, K., Lofts, K., \& Davidian, G. "A rights-based approach to indigenous women and gender inequities in resource development in northern Canada." Review of European, Comparative \& International Environmental Law, 27 (2018): 63-74. doi: 10.1111/reel.12240.

Kuokkanen, R. “Globalization as racialized, sexualized violence.” International Feminist Journal of Politics, 10, no. 2 (2008): 216-233. doi:10.1080/14616740801957554

Laboucan-Massimo, Melina. "Climate Justice Must Include Gender Justice,” David Suzuki Foundation. (2018). Retrieved from https://davidsuzuki.org/story/climate-justice-mustinclude-gender-justice/.

Landry, Kassandra. “'Camp Syndrome?' Exploring Frontier Masculinity in Alberta’s Oil Production Culture: Oil Worker and Sex Worker Perspectives." MA Thesis, University of Alberta, 2017, https://era.library.ualberta.ca/items/475e2003-30e3-4ea9-9eee346318ef71f8/view/4acc24ec-cc8c-4c83-ad891162b4b13117/Landry_Kassandra_M_201709_MA.pdf.

Lu, Xiaohe. "Business Ethics and Karl Marx's Theory of Capital - Reflections on Making use of Capital for Developing China's Socialist Market Economy." Journal of Business Ethics 91, no. 1 (2010): 95-111. doi:10.1007/s10551-009-0070 8. http://resolver.scholarsportal.info/resolve/01674544/v91i0001/95_beakmtfdcsme.

Martin, Carol Muree, Walia, Harsha. "Red Women Rising.” Downtown Eastside Women's Centre. (2019). Retrieved from http://dewc.ca/wp-content/uploads/2019/03/MMIWReport-Final-March-10-WEB.pdf.

Medium. "Karl Marx's 'Wage Labor and Capital'”. A Medium Corporation. Retrieved from https://medium.com/@mdowns1611/notes-on-karl-marxs-wage-labor-and-capitaldecdc49b566b.

Morin, Brandi. "Pipeline 'man camps' loom over B.C.'s Highways of Tears." Canada's National Observer. September 21, 2017.

https://www.nationalobserver.com/2017/09/21/news/pipeline-man-camps-loom-over-bcshighway-tears.

Morton, K. "Hitchhiking and Missing and Murdered Indigenous Women: A Critical Discourse Analysis of Billboards on the Highway of Tears." The Canadian Journal of Sociology, 
no. 3 (2016): 299-326. Retrieved from

https://www.jstor.org/stable/canajsocicahican.41.3.299.

National Inquiry into Missing Murdered Indigenous Women and Girls. "Interim Report: Our Women and Girls Are Sacred." (2017). Retrieved from http://www.mmiwg-ffada.ca/wpcontent/uploads/2018/03/ni-mmiwg- interim-report.pdf.

National Inquiry into Missing and Murdered Indigenous Women and Girls. "Reclaiming Power and Place," (2019). Retrieved from https://www.mmiwg-ffada.ca/wpcontent/uploads/2019/06/Final_Report_Vol_1a.pdf.

Natural Resources Canada. “10 Key Facts on Canada's Natural Resources.” Government of Canada. August 2018. Retrieved from https://www.nrcan.gc.ca/sites/www.nrcan.gc.ca/files/files/pdf/10_key_facts_NatResource s_2018_e.pdf.

Oxfam International, "Position Paper on Gender Justice and the Extractive Industries," March 2017. Retrieved from https://42kgab3z3i7s3rm1xf48rq44-wpengine.netdna-ssl.com/wpcontent/uploads/2017/05/position pater on gender justice and th extractive industries _oxfam.pdf.

Park, Jonathan T. "Climate Change and Capitalism." Consilience, no. 14 (2015): 189-206. http://www.jstor.org/stable/26188749.

Plan International. (2019). Gender-Based Violemnce. Retrieved from Plan International: https://plancanada.ca/gender-based-violence

Preston, Jen. "Neoliberal Settler Colonialism, Canada and the Tar Sands." Race \& Class 55, no. 2 (October 2013): 42-59. doi:10.1177/0306396813497877.

Roudometkina, Arina. "Trafficking on Indigenous Women and Girls in Canada." Native Women's Association of Canada. (2018). Retrieved from https://www.ourcommons.ca/Content/Committee/421/JUST/Brief/BR10002955/brexternal/NativeWomensAssociationOfCanada-e.pdf.

Royal Canadian Mounted Police. Missing Murdered Aboriginal Women: A National Operational Overview. (2014). Retrieved from http://www.rcmpgrc.gc.ca/wam/media/460/original/0cbd8968a049aa0b44d343e76b4a9478.pdf.

Statistics Canada. "Aboriginal Peoples in Canada: Key Results from the 2016 Census.” 2017. Retrieved from https://www150.statcan.gc.ca/n1/daily-quotidien/171025/dq171025aeng.htm.

Status of Women Canada. "What is GBA+?". Government of Canada. Retrieved from https://cfc-swc.gc.ca/gba-acs/index-en.html. 
Story, Brett. Prison Land: Mapping Carceral Power across Neoliberal America. Minneapolis: University of Minnesota Press, 2019.

Trading Economics. “Canada GDP.” Trading Economics. 2018. Retrieved from https://tradingeconomics.com/canada/gdp.

Truth and Reconciliation Commission of Canada. "Truth and Reconciliation Commission of Canada: Calls to Action.” TRCC. 2015. Retrieved from http://nctr.ca/assets/reports/Calls to Action English2.pdf.

United Nations. "Declaration on the Elimination of Violence Against Women," OHCHR, December 1993. Retrieved from https://www.ohchr.org/Documents/ProfessionalInterest/eliminationvaw.pdf.

United Nations Human Rights Office of the High Commissioner. "Free, Prior and Informed Consent of Indigenous Peoples." September 2013. Retrieved from https://www.ohchr.org/Documents/Issues/ipeoples/freepriorandinformedconsent.pdf.

Wingrove, Josh. "Hunger strikers seek money for women's shelter in Fort McMurray." The Globe and Mail. August 2010. Retrieved from https://www.theglobeandmail.com/news/national/hunger-strikers-seek-money-forwomens-shelter-in-fort-mcmurray/article1377238/.

Women's Earth Alliance and Native Youth Sexual Health Network. "VIOLENCE ON THE LAND, VIOLENCE ON OUR BODIES Building an Indigenous Response to Environmental Violence." 2016. Retrieved from http://landbodydefense.org/uploads/files/VLVBReportToolkit2016.pdf

World Council of Churches. "Statement on the doctrine of discovery and its enduring impact on Indigenous Peoples." February 2012, Retrieved from https://www. oikoumene.org/en/resources/documents/executive-committee/2012-02/statement-on-thedoctrine-of-discovery-and-its-enduring-impact-on-indigenous-peoples

Work Camps Regulation, Alberta Regulation 218/2002. http://www.qp.alberta.ca/documents/Regs/2002 218.pdf. 